Article

\title{
Approach to Petiole Sap Nutritional Diagnosis Method by Empirical Model Based on Climatic and Growth Parameters
}

\author{
Alfonso Llanderal ${ }^{1,2}$ (D) , Pedro García-Caparrós ${ }^{2,+}$, José Pérez-Alonso ${ }^{3,+}{ }^{(D)}$, \\ Juana Isabel Contreras ${ }^{4,+} \mathbb{D}$, María Luz Segura ${ }^{4,+}$, Juan Reca ${ }^{3}(\mathbb{D})$ and María Teresa Lao ${ }^{2, *(\mathbb{D})}$ \\ 1 Faculty of Technical Education for Development, Catholic University of Santiago of Guayaquil, \\ Av. C. J. Arosemena Km. 1.5, 09014671 Guayaquil, Ecuador; alfonsollanderal@hotmail.com \\ 2 Agronomy Department of Superior School Engineering, University of Almeria, CIAIMBITAL, Agrifood \\ Campus of International Excellence, ceiA3. Ctra. Sacramento s/n, La Cañada de San Urbano, 04120 Almería, \\ Spain; pedrogar123@hotmail.com \\ 3 Engineering Department of Higher Engineering School, University of Almeria, Ctra. Sacramento s/n, \\ La Cañada de San Urbano, 04120 Almería, Spain; jpalonso@ual.es (J.P.-A.); jreca@ual.es (J.R.) \\ 4 Institute of Research and Training in Agriculture and Fishery (IFAPA), Junta of Andalusia, La Mojonera, \\ 04745 Almería, Spain; marial.segura@juntadeandalucia.com (J.I.C.); \\ juanai.contreras@juntadeandalucia.es (M.L.S.) \\ * Correspondence: mtlao@ual.es; Tel.: +34-950-015-876; Fax: +34-950-015-939 \\ + The authors contributed equally to this work.
}

Received: 15 December 2019; Accepted: 28 January 2020; Published: 29 January 2020

\begin{abstract}
The aim of this work is to evaluate the relationship between the nutrient concentration in petiole sap and different agronomic and climatic variables for a tomato crop grown in a greenhouse in Mediterranean conditions. In addition, the persistence of the nutrient concentration in petiole sap was investigated with the aim of determining the sampling period that implies the best trade-off nutritional information. The experiment consisted of the selection of 20 sampling points inside the greenhouse. The samples of petiole, fully expanded leaf, and soil solution samples were collected weekly from 86 to 163 days after transplanting. Chloride, $\mathrm{NO}_{3}{ }^{-}-\mathrm{N}, \mathrm{H}_{2} \mathrm{PO}_{4}{ }^{-}-\mathrm{P}, \mathrm{Na}^{+}, \mathrm{K}^{+}, \mathrm{Ca}^{2+}$, and $\mathrm{Mg}^{2+}$ concentrations were determined in petiole sap and soil solution obtained by suction cups. Nitrogen, $\mathrm{P}, \mathrm{K}, \mathrm{Cl}$, and $\mathrm{Na}$ concentrations were also determined in leaf. Finally, the petiole sap nutritional diagnosis method is the highest sensitive nutritional diagnosis method which compares soil solution and nutrient leaf content related to yield, and the statistical analysis performed in this research demonstrates that crop evapotranspiration (ETc), vapor pressure deficit (DPV), and leaf area index (LAI) are considered the most significant variables that allow the development of these empirical prediction models regarding nutrient concentration in petiole sap.
\end{abstract}

Keywords: crop evapotranspiration; leaf analysis; leaf area index; petiole sap; soil solution; vapor pressure deficit (VPD)

\section{Introduction}

The method of petiole sap analysis is used for the determination of crop nutritional status since 1920 [1,2] and is carried out on fresh material, giving a semiquantitative evaluation of the extractable nutrients that are present in soluble inorganic forms in the plant just at the sampling moment [3].

Xylem and phloem sap plus apoplastic solution are used to determine the nutrient concentration in a crop [4], but in order to establish a crop a nutritional diagnostic is required for comparison with the sufficiency ranges of this crop [5]. The sufficiency ranges are commonly used to interpret plant nutrient composition as well as nutrient deficiency, sufficiency, luxury consumption, or excess [6]. 
There are several factors which can modify the nutrient sap concentration, such as fertilizer application, light intensity, phenological stage, and sampling position [2,7-9]. Regarding fertilizer application, Ikeda [10] reported a significant decrease in sap concentration of $\mathrm{NO}_{3}{ }^{-}, \mathrm{H}_{2} \mathrm{PO}_{4}{ }^{-}, \mathrm{Ca}^{2+}$, and $\mathrm{Mg}^{2+}$ in tomato grown in nutrient solution after 10 days without nutrient solution. Considering the light intensity, Leyva et al. [11] found that in a tomato crop in the cycle of autumn-winter, when the days are shorter and the light intensity is lower than in summer months, there is a decrease in the synthesis of carboxylates and soluble carbohydrates used as osmolytes in plants resulting in a higher uptake of $\mathrm{NO}_{3}{ }^{-}$to be used as osmolytes. Cadahía [12] found a significant variation in the concentration of $\mathrm{Cl}^{-}, \mathrm{NO}_{3}{ }^{-}-\mathrm{N}, \mathrm{H}_{2} \mathrm{PO}_{4}{ }^{-}-\mathrm{P}, \mathrm{SO}_{4}{ }^{2-}-\mathrm{S}, \mathrm{Na}^{+}, \mathrm{K}^{+}, \mathrm{Ca}^{2+}$, and $\mathrm{Mg}^{2+}$ in sap throughout the different phenological stages of a tomato crop. Garcia and Azuara [13] reported a high variation between sampled leaves selected (young leaves, fully grown young leaves, mature leaves, and older leaves), reporting that the concentration of $\mathrm{H}_{2} \mathrm{PO}_{4-}-\mathrm{P}$ was higher in the young leaf because this ion is located in places with maximum metabolic activity. Similiarly, Llanderal et al. [14] reported that the selection of sampled leaves (fully grown young leaves, mature leaves, and older leaves) did not modify the $\mathrm{Ca}^{2+}, \mathrm{Cl}^{-}, \mathrm{SO}_{4}{ }^{2-} \mathrm{S}$, and $\mathrm{Na}^{+}$concentrations, whereas $\mathrm{NO}_{3}{ }^{-}-\mathrm{N}, \mathrm{K}^{+}, \mathrm{Mg}^{2+}$, and $\mathrm{H}_{2} \mathrm{PO}_{4}{ }^{-}-\mathrm{P}$ concentrations showed great variability due to the selection of the sample leaf, therefore it is necessary to be careful with the sample selection.

The wide variability of sufficiency ranges in tomato proposed by different researchers includes: $\mathrm{NO}_{3}{ }^{-}-\mathrm{N}\left(700-1210 \mathrm{mg} \mathrm{L}^{-1}\right), \mathrm{K}^{+}\left(3500-5000 \mathrm{mg} \mathrm{L}^{-1}\right)$ [2], $\mathrm{PO}_{4} \mathrm{H}_{2}{ }^{-}-\mathrm{P}\left(35-300 \mathrm{mg} \mathrm{L}^{-1}\right), \mathrm{Ca}^{2+}(280-1420$ $\left.\mathrm{mg} \mathrm{L}^{-1}\right), \mathrm{Mg}^{2+}\left(190-2000 \mathrm{mg} \mathrm{L}^{-1}\right)$ [12], $\mathrm{Cl}^{-}\left(750-4500 \mathrm{mg} \mathrm{L}^{-1}\right)$, and $\mathrm{Na}^{+}\left(50-400 \mathrm{mg} \mathrm{L}^{-1}\right)$ [15] which can be related to the different factors aforementioned. Therefore, the aim of this work is to evaluate different parameters in relation with the nutrient concentration in petiole sap in a tomato crop in a greenhouse cultivated in Mediterranean conditions and to propose an empirical model in order to determine the nutrient concentration in petiole sap.

\section{Materials and Methods}

\subsection{Plant Material and Experimental Conditions}

This study was carried out in an Almeria-type greenhouse $\left(1024 \mathrm{~m}^{2}\right)$ located in the "UAL-ANECOOP; Research Center" in a culture system called "mulching sandy soil", which is the standard cropping system of the area, constituted by a layer of grave-sand (granulometry variable compound of particles smaller than $1 \mathrm{~mm}$ up to $5 \mathrm{~mm}$ ), an intermediate layer of organic matter (it is usually placed in layer or mixed whole or in part with the topsoil), and natural soil (variable texture which can vary from clay to sandy loam, or the autochthonous soil) [16]. The tomatoes (Solanum lycopersicum cv. "Ramyle RZ F1") had a planting density of 2 plants per $\mathrm{m}^{2}$ in a crop cycle during autumn-winter (15/08/2012 to 25/01/2013). The nutrients were applied by means of fertigation with a trickle-feed distribution irrigation system with a flow of $3 \mathrm{~L} \mathrm{~h}^{-1}$ per emitter. The nutrient solution contained (in mmol L${ }^{-1}$ ): $\mathrm{Cl}^{-} 6.44, \mathrm{NO}_{3}{ }^{-} 13.00, \mathrm{H}_{2} \mathrm{PO}_{4}{ }^{-} 1.26, \mathrm{SO}_{4}{ }^{2-} 6.82, \mathrm{~K}^{+} 7.62, \mathrm{Ca}^{2+} 5.50$, $\mathrm{Mg}^{2+} 3.90, \mathrm{Na}^{+} 7.54$, an electrical conductivity (EC) of $3.40 \mathrm{dS} \mathrm{m}^{-1}$, and a $\mathrm{pH}$ value of 5.80 and was applied from the first day of planting. The nutrient solution derived from tap water $(\mathrm{pH}, 7.7, \mathrm{EC} 1.9$ $\mathrm{dS} \mathrm{m}{ }^{-1}, \mathrm{Cl}^{-}$6.44, $\mathrm{NO}_{3}{ }^{-} 0.36, \mathrm{SO}_{4}{ }^{2-} 5.36, \mathrm{~K}^{+} 0.28, \mathrm{Ca}^{2+} 3.19, \mathrm{Mg}^{2+} 3.90$, and $\mathrm{Na}^{+} 7.54 \mathrm{mmol} \mathrm{L}^{-1}$ ) and phosphoric acid $\left(\mathrm{H}_{3} \mathrm{PO}_{4}\right)$, nitric acid $\left(\mathrm{HNO}_{3}\right)$, potassium nitrate $\left(\mathrm{KNO}_{3}\right)$, potassium sulphate $\left(\mathrm{K}_{2} \mathrm{SO}_{4}\right)$, and calcium nitrate $\left(\mathrm{Ca}\left(\mathrm{NO}_{3}\right)_{2}\right)$ supplies. The total water applied during the experimental period was $244.3 \mathrm{~L} \mathrm{~m}^{-2}$ modified weekly according to the water requirements of the plant, ranging from 0.9 to $2.1 \mathrm{~L} \mathrm{~m}^{-2}$ day $^{-1}$ over the entire growth period.

\subsection{Experimental Design and Parameters Assessed}

The experimental design consisted of the selection of 20 sample points inside the greenhouse (Figure 1). One sample of petiole and leaf of fully young leaves in the upper part and soil solution (SS) per sample point were collected weekly from 86 (October) to 163 (January) days after transplanting 
(DAT) with a total of 240 samples. Additionally, ripe fruits of the 20 plants were harvested weekly from 107 to 163 DAT and weighed to determine the yield.

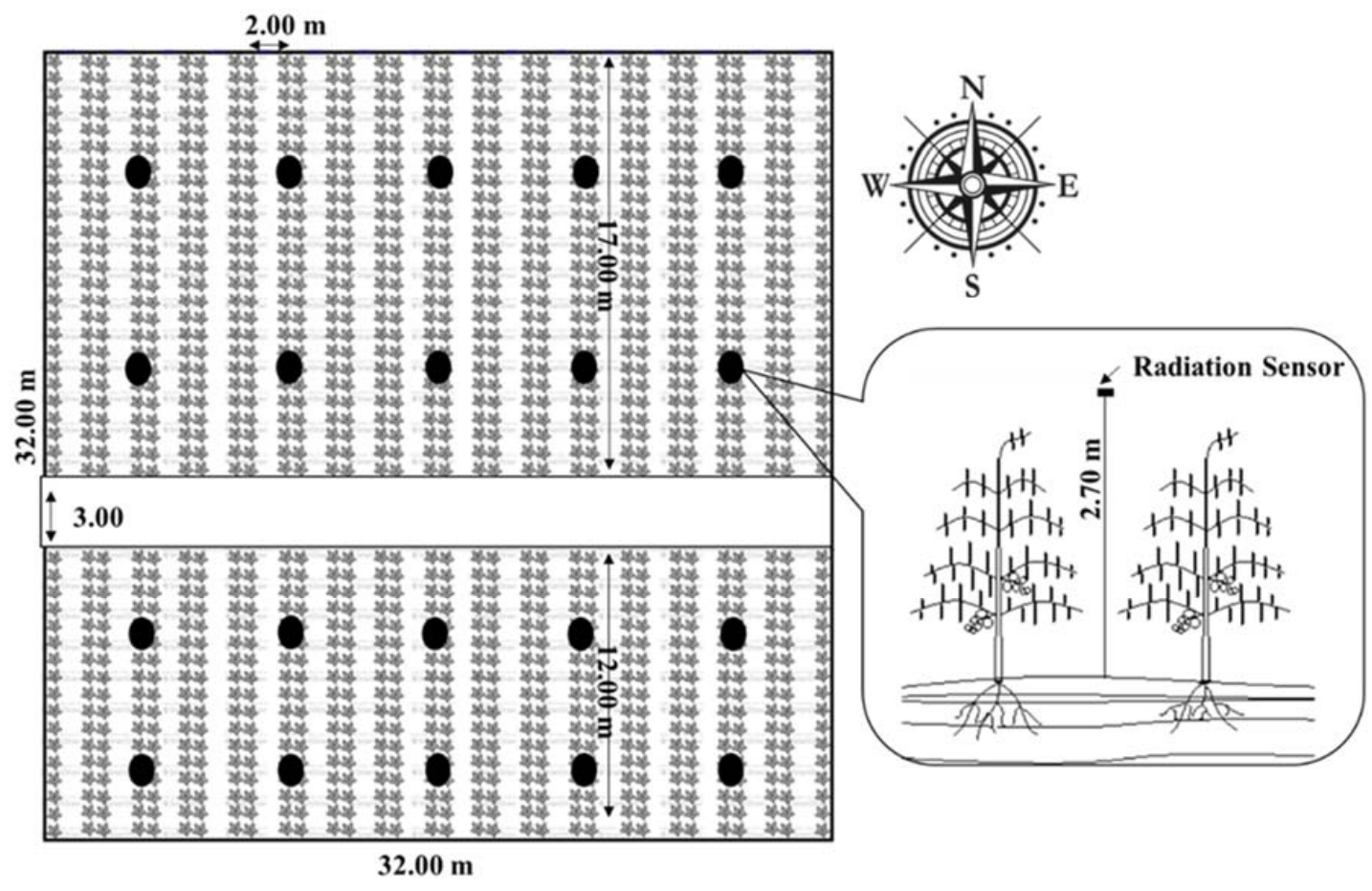

Figure 1. Location of sample points inside the greenhouse.

Plant parameters: Leaf area index (LAI) was estimated using the equation proposed by Medrano et al. [17] for tomato crop (Equation (1)):

$$
\mathrm{LAI}=(\mathrm{a}+\mathrm{b}) /((1-\exp (-(\mathrm{DAT}-\mathrm{c}) \times \mathrm{d}))
$$

where $\mathrm{a}=-0.46, \mathrm{~b}=5.1, \mathrm{c}=43.2, \mathrm{~d}=19.1$, and DAT $=$ days after transplanting.

Climatic conditions: The climatic parameters inside the greenhouse were determined with 4 dry and wet bulb air temperature models (Nutricontrol, Murcia, Spain) by means of wire resistance thermometers in aspirated boxes (temperature and relative humidity) and 20 pyranometers (models CS300, Campbell Scientific., Barcelona, Spain) in order to determine the photosynthetically active radiation (PAR) at a height of $2.40 \mathrm{~m}$. Crop evapotranspiration (ETc) was estimated using the equation proposed by Bailey et al. [18] (Equation (2)):

$$
\mathrm{T}=\mathrm{A} \times f_{1}(\mathrm{LAI}) \mathrm{R}+\mathrm{B} \times \mathrm{LAI} \times \mathrm{DPV}
$$

where $\mathrm{T}\left(\mathrm{mm} \mathrm{day}^{-1}\right)$ is the crop transpiration, $\mathrm{R}$ is the solar radiation $\left(\mathrm{MJ} \mathrm{m}^{-2} \mathrm{day}^{-1}\right)$, DPV is vapor pressure deficit $(\mathrm{kPa}), \mathrm{A}$ and $\mathrm{B}\left(\mathrm{mm} \mathrm{day}{ }^{-1} \mathrm{kPa}^{-1}\right)$ are both crop coefficients, which must be determined experimentally for each crop. The factor $f_{1}$ is a dimensionless exponential function that considers the interception of the radiation by the canopy as a function of an extinction coefficient ( $\mathrm{k}$ ) (Equation (3)):

$$
\mathrm{T}=1 \mathrm{e}^{\wedge}((-\mathrm{k} \cdot \mathrm{LAI}))
$$

Suction cups: Each suction cup was placed $10 \mathrm{~cm}$ from the neck of the plant with $15 \mathrm{~cm}$ of depth in order to extract the soil solution to a vacuum of $-70 \mathrm{kPa}$, according to the methodology described by Lao et al. [19]. The nutrient parameters measured in the soil solution were as follows: $\mathrm{pH}$ and EC with a pH meter (model Milwaukee pH 52; Rocky Mount, NC, USA) and EC meter (model Milwaukee CE 66; Rocky Mount, NC, USA), respectively. Anions $\left(\mathrm{Cl}^{-}, \mathrm{NO}_{3}{ }^{-}\right.$, and $\left.\mathrm{H}_{2} \mathrm{PO}_{4}{ }^{-}\right)$and cations $\left(\mathrm{K}^{+}\right.$, 
$\mathrm{Ca}^{2+}, \mathrm{Mg}^{2+}$, and $\mathrm{Na}^{+}$) concentrations were determined by HPLC (model 883 Basic IC Plus, anions ion exchange column model Metrosep A SUPP 4, cations ion exchange column model Metrosep C4 100, IC conductivity detector range $\left(0-15,000 \mu \mathrm{S} \mathrm{cm}^{-1}\right)$, Metrohm, Herisau, Switzerland), as described by Csáky and Martínez-Grau [20].

Petiole sap: Samples of fully developed young leaves were selected and cleaned using a damp cloth cleaved in fractions of $0.5 \mathrm{~cm}$ which were frozen at $-16{ }^{\circ} \mathrm{C}$ for $24 \mathrm{~h}$. Petiole sap (xylem and phloem sap plus the apoplastic, cytosolic, and vacuolar solution) extraction was performed using a hydraulic press, according to the methodology described by Cadahía [21]. In the petiole sap, $\mathrm{Cl}^{-}$, $\mathrm{NO}_{3}{ }^{-}-\mathrm{N}, \mathrm{H}_{2} \mathrm{PO}_{4}{ }^{-}-\mathrm{P}, \mathrm{Na}^{+}, \mathrm{K}^{+}, \mathrm{Ca}^{2+}$, and $\mathrm{Mg}^{2+}$ concentrations were determined by high-performance liquid chromatography (model 883 Basic IC Plus, anions ion exchange column model Metrosep A SUPP 4, cations ion exchange column model Metrosep C4 100, IC conductivity detector range (0-15,000 $\left.\mu \mathrm{S} \mathrm{cm}^{-1}\right)$, Metrohm, Herisau, Switzerland), as described by Csáky and Martínez-Grau [20].

Leaf analysis: The uppermost, fully expanded leaves were sampled. Samples were washed with distilled water and then dried to constant weight at $60^{\circ} \mathrm{C}$ in a NüveE FN500 oven. After drying, leaf samples were then ground and divided into two subsamples: one was used to determine the soluble ionic forms $\left(\mathrm{NO}_{3}{ }^{-}, \mathrm{SO}_{4}{ }^{2-}\right.$, and $\left.\mathrm{Cl}^{-}\right)$extracted with water and analyzed by HPLC (high-performance liquid chromatography, model Metrohm 883 Basic IC Plus) as described by Csáky and Martínez-Grau [20] and the other subsample was digested with sulfuric acid $\left(\mathrm{H}_{2} \mathrm{SO}_{4}, 96 \%\right)$ in the presence of hydrogen peroxide $\left(\mathrm{H}_{2} \mathrm{O}_{2}\right)$ at $300^{\circ} \mathrm{C}$ to determine organic $\mathrm{N}$ and total $\mathrm{P}$ concentration colorimetrically. Organic $\mathrm{N}$ [22] was quantified at $630 \mathrm{~nm}$ and total $\mathrm{P}$ by the molybdo-vanadate method at $430 \mathrm{~nm}$ [23]. Total N was calculated as the sum of organic $\mathrm{N}$ and $\mathrm{NO}_{3}{ }^{-}-\mathrm{N}$ concentration. Total $\mathrm{K}^{+}$and $\mathrm{Na}^{+}$were directly measured by flame spectrophotometry [24] using a Jenway PFP7 flame photometer.

\subsection{Statistical Analysis}

The data obtained were analyzed and the average, minimum, and maximum values of all measured parameters were estimated in climatic variables and nutrient concentrations in the sap, soil solution, and leaf analysis. With the aim of developing functional relationships between each nutrient concentration in sap and the climatic variables and nutrient concentrations in the soil solution, a multivariate regression analysis was carried out.

To simplify the model and select the independent variables that most significantly affect the sap concentrations, a stepwise regression was performed. The stepwise regression procedure successively adds or removes variables from the regression with the aim of obtaining the simplest model containing only significant predictors, but without excluding useful variables.

An autocorrelation analysis was also performed with the temporal series of nutrient concentrations in petiole sap. The autocorrelation function is a measure of the correlation between observations of a time series that are separated by " $k$ " time units. This autocorrelation analysis can be useful for detection if the concentration of a specific nutrient is dependent on the concentrations of previous sampling intervals. When a specific nutrient shows no temporal autocorrelation, it means that its concentration varies rapidly and randomly during the sampling period which can be regarded as a measure of the mobility of the nutrient in the sap. This autocorrelation analysis can be useful to establish the modeling of the nutrient considering its temporal persistence and establish appropriate sampling intervals.

The statistical analyses were conducted using the Statgraphics Centurion XVI@ (Statpoint Technologies, Inc. Warrenton, VA, USA) software with different confident levels $(p<0.05$ and $p<0.01$, respectively).

\section{Results}

\subsection{Growth Conditions of the Experiment}

The climatic conditions during the experiment and the parameters used to evaluate the development of the plant are shown in Table 1. The ranges for the climatic parameters were: ETc from 1.17 to 
$2.43 \mathrm{~mm} \mathrm{day}^{-1}$, global radiation inside the greenhouse from 4.03 to $8.63 \mathrm{MJ} \mathrm{m}^{-2}$ day $^{-1}$, temperature from 10.50 to $17.14{ }^{\circ} \mathrm{C}$, relative humidity from 71.63 to $96.78 \%$, vapor pressure deficit (VPD) absolute values from 0.21 to $0.53 \mathrm{kPa}$. The ranges for plant parameters considered were: LAI from 4.15 to 4.63 and yield from 7.2 to $9.4 \mathrm{~kg} \mathrm{~m}^{-2}$. Other growth parameters estimated, such as plant height and relative growth rate, did not correlate with the other parameters (data not shown).

Table 1. Average, maximum, and minimum values of the climatic parameters (crop evapotranspiration (ETc) $\left(\mathrm{mm} \mathrm{day}^{-1}\right)$, global radiation $(\mathrm{Rad})\left(\mathrm{MJ} \mathrm{m}^{-2}\right.$ day), temperature $\left({ }^{\circ} \mathrm{C}\right)$, relative humidity $(\%)$, vapor pressure deficit (VPD) (kPa), and plant parameters (leaf area index (LAI) and yield). $\mathrm{N}=240$ samples.

\begin{tabular}{|c|c|c|c|c|c|c|c|}
\hline & \multicolumn{5}{|c|}{ Climatic Parameters } & \multicolumn{2}{|c|}{ Plant Parameters } \\
\hline & ETc & Rad. & $\mathbf{T}^{\mathrm{a}}$ & RH & VPD & LAI & Yield \\
\hline & $\left(\mathrm{mm} \mathrm{day}^{-1}\right)$ & $\left(\mathrm{MJ} \mathrm{m}^{-2} \mathrm{day}^{-1}\right)$ & $\left({ }^{\circ} \mathrm{C}\right)$ & $(\%)$ & $(\mathbf{k P a})$ & $\left(\mathrm{m}^{2} \mathrm{~m}^{-2}\right)$ & $\left(\mathrm{kg} \mathrm{m}^{-2}\right)$ \\
\hline Min & 1.17 & 8.03 & 10.50 & 71.63 & 0.21 & 4.15 & 7.2 \\
\hline Max & 2.43 & 6.63 & 17.14 & 96.78 & 0.53 & 4.63 & 9.4 \\
\hline Ave & 1.79 & 4.78 & 14.51 & 85.43 & 0.32 & 4.52 & 7.9 \\
\hline
\end{tabular}

Table 2 shows the average, maximum, and minimum values of the different parameters analyzed in soil solution, petiole sap, and leaf.

Table 2. Average, maximum, and minimum of soil solution values ( $\mathrm{pH}$ and electrical conductivity (EC) $\left.\left(\mathrm{dS} \mathrm{m}{ }^{-1}\right)\right)$ and concentrations $\left(\mathrm{Cl}^{-}, \mathrm{NO}_{3}-, \mathrm{H}_{2} \mathrm{PO}_{4}{ }^{-}, \mathrm{K}^{+}, \mathrm{Na}^{+}, \mathrm{Ca}^{2+}\right.$, and $\left.\mathrm{Mg}^{2+}\left(\mathrm{mmol} \mathrm{L}^{-1}\right)\right)$, petiole sap concentrations $\left(\mathrm{Cl}^{-}, \mathrm{NO}_{3}{ }^{-}-\mathrm{N}, \mathrm{H}_{2} \mathrm{PO}_{4}^{-}-\mathrm{P}, \mathrm{Na}^{+}, \mathrm{K}^{+}, \mathrm{Ca}^{2+}\right.$, and $\left.\mathrm{Mg}^{2+}\left(\mathrm{mg} \mathrm{L}^{-1}\right)\right)$, and leaf content $(\mathrm{N}, \mathrm{P}$, $\mathrm{K}, \mathrm{S}, \mathrm{Na}$, and $\left.\mathrm{Cl}\left(\mathrm{mg} \mathrm{g}^{-1} \mathrm{DW}\right)\right)$. $\mathrm{N}=240$ samples.

\begin{tabular}{|c|c|c|c|c|c|c|c|c|c|}
\hline & \multicolumn{9}{|c|}{ Soil Solution $\left(\mathrm{mmol} \mathrm{L}^{-1}\right)$} \\
\hline & $\mathrm{pH}$ & $E C\left(d S m^{-1}\right)$ & $\mathrm{Cl}^{-}$ & $\mathrm{NO}_{3}{ }^{-}$ & $\mathrm{H}_{2} \mathrm{PO}_{4}^{-}$ & $\mathrm{Na}^{+}$ & $\mathrm{K}^{+}$ & $\mathrm{Ca}^{2+}$ & $\mathrm{Mg}^{2+}$ \\
\hline Min & 7.43 & 3.15 & 8.91 & 12.22 & 0.18 & 9.71 & 6.24 & 7.65 & 6.57 \\
\hline Max & 7.75 & 4.41 & 10.12 & 23.33 & 0.20 & 11.63 & 13.63 & 8.73 & 8.22 \\
\hline \multirow[t]{3}{*}{ Ave } & 7.59 & 3.62 & 9.46 & 18.24 & 0.22 & 10.51 & 9.22 & 8.15 & 7.31 \\
\hline & \multicolumn{9}{|c|}{ Petiole Sap $\left(\mathrm{mg} \mathrm{L}^{-1}\right)$} \\
\hline & - & - & $\mathrm{Cl}^{-}$ & $\mathrm{NO}_{3}{ }^{-}-\mathrm{N}$ & $\mathrm{H}_{2} \mathrm{PO}_{4}{ }^{-}-\mathrm{P}$ & $\mathrm{Na}^{+}$ & $\mathrm{K}^{+}$ & $\mathrm{Ca}^{2+}$ & $\mathrm{Mg}^{2+}$ \\
\hline Min & - & - & 1041 & 1037 & 26.33 & 508.9 & 4000 & 486.1 & 1275 \\
\hline Max & - & - & 1202 & 1408 & 185.3 & 608.1 & 4869 & 640.9 & 1965 \\
\hline \multirow[t]{3}{*}{ Ave } & - & - & 1118 & 1247 & 72.83 & 552.2 & 4441 & 552.2 & 1674 \\
\hline & \multicolumn{9}{|c|}{ Leaf $\left(\mathrm{mg} \mathrm{g}^{-1} \mathrm{DW}\right)$} \\
\hline & - & - & $\mathrm{Cl}$ & $\mathbf{N}$ & $\mathbf{P}$ & $\mathbf{N a}$ & $\mathbf{K}$ & - & - \\
\hline Min & - & - & 6.29 & 33.5 & 3.42 & 4.58 & 46.3 & - & - \\
\hline Max & - & - & 6.83 & 39.2 & 5.38 & 7.38 & 54.6 & - & - \\
\hline Ave & - & - & 6.54 & 36.3 & 4.27 & 5.81 & 50.8 & - & - \\
\hline
\end{tabular}

\subsection{Petiole Sap Nutrients, Climatic Parameters, and Nutrients in Soil Solution}

The main reasons for the great variability between nutrient concentration in the petiole sap may be ascribed to climatic conditions, plant growth, and nutrient concentration in the soil solution. In order to determine these relationships, correlation coefficients between all parameters in petiole sap were calculated (Table 3). There was a high positive correlation between ETc and nutrient concentrations in petiole sap for all nutrients. Additionally, a negative correlation was determined between global radiation and $\mathrm{NO}_{3}{ }^{-}-\mathrm{N}$ concentration in sap. Nevertheless, no correlation was found between temperature and nutrient concentrations in petiole sap, only $\mathrm{Ca}^{2+}$ concentration showed a moderately negative correlation with relative humidity $(\mathrm{RH})$. Similarly to ETc, DPV showed a high 
positive correlation with all the nutrients studied in the petiole sap. On the other hand, LAI showed a high $\left(\mathrm{Cl}^{-}, \mathrm{NO}_{3}{ }^{-}-\mathrm{N}, \mathrm{Ca}^{2+}\right.$ and $\left.\mathrm{Mg}^{2+}\right)$ and moderate $\left(\mathrm{H}_{2} \mathrm{PO}_{4}{ }^{-}-\mathrm{P}, \mathrm{Na}^{+}\right.$and $\left.\mathrm{K}^{+}\right)$positive correlation with the nutrients in the sap. Finally, the only significant correlation between the soil solution and nutrients in sap was in $\mathrm{NO}_{3}{ }^{-}-\mathrm{N}(r=0.68)$.

Table 3. Correlation coefficients ( $\mathrm{r}$ ) between petiole sap concentrations $\left(\mathrm{Cl}^{-}, \mathrm{NO}_{3}{ }^{-}-\mathrm{N}, \mathrm{H}_{2} \mathrm{PO}_{4}{ }^{-}-\mathrm{P}, \mathrm{Na}^{+}\right.$, $\mathrm{K}^{+}, \mathrm{Ca}^{2+}$, and $\left.\mathrm{Mg}^{2+}\right)\left(\mathrm{mg} \mathrm{L}^{-1}\right)$ and the climatic parameters $\left(\mathrm{ET}_{\mathrm{c}}\left(\mathrm{mm} \mathrm{day}^{-1}\right)\right.$, global radiation $\left(\mathrm{MJ} \mathrm{m}^{-2}\right.$ day $\left.{ }^{-1}\right)$, temperature $\left({ }^{\circ} \mathrm{C}\right)$, relative humidity $(\mathrm{RH})(\%)$ and vapor pressure deficit (VPD) $(\mathrm{kPa}), \mathrm{LAI}(-)$, and soil solution (SS) nutrient concentrations $\left(\mathrm{Cl}^{-}, \mathrm{NO}_{3}{ }^{-}, \mathrm{H}_{2} \mathrm{PO}_{4}{ }^{-}, \mathrm{SO}_{4}{ }^{2-}, \mathrm{K}^{+}, \mathrm{Na}^{+}, \mathrm{Ca}^{2+}\right.$, and $\left.\mathrm{Mg}^{2+}\right)$ $(\mathrm{mmol} \mathrm{L}-1)$.

\begin{tabular}{cccccccc}
\hline Parameters & ETc & Rad. & Temp. & RH & VPD & LAI & SS \\
\hline $\mathrm{Cl}^{-}$ & $0.88^{*}$ & -0.06 & -0.29 & -0.30 & $0.83^{*}$ & $-0.84^{*}$ & -0.15 \\
$\mathrm{NO}_{3}{ }^{-}-\mathrm{N}$ & $0.85^{*}$ & $-0.61^{*}$ & -0.32 & -0.20 & $0.80^{*}$ & $-0.84^{*}$ & $0.68^{*}$ \\
$\mathrm{H}_{2} \mathrm{PO}_{4}^{-}-\mathrm{P}$ & $0.87^{*}$ & 0.32 & 0.25 & 0.18 & $0.75^{*}$ & $-0.74^{*}$ & 0.06 \\
$\mathrm{Na}^{+}$ & $0.68^{*}$ & 0.05 & 0.30 & 0.06 & $0.53^{*}$ & $-0.69^{*}$ & 0.11 \\
$\mathrm{~K}^{+}$ & $0.65^{*}$ & 0.27 & 0.24 & 0.38 & $0.63^{*}$ & $-0.52^{*}$ & -0.21 \\
$\mathrm{Ca}^{2+}$ & $0.85^{*}$ & -0.31 & -0.34 & $-0.69^{*}$ & $0.87^{*}$ & $0.79^{*}$ & 0.12 \\
$\mathrm{Mg}^{2+}$ & $0.82^{*}$ & -0.33 & 0.25 & -0.24 & $0.75^{*}$ & $0.91^{*}$ & 0.13 \\
\hline
\end{tabular}

${ }^{*}$ indicates significant differences at $p<0.05$.

Table 4 shows the autocorrelation between nutrient concentrations in petiole sap over time, where the sap nutrient concentrations corresponding to a week are related to the sap nutrient concentrations after one week (1), or 2 weeks (2), 3 weeks (3), and 4 weeks (4). It is important to highlight that $\mathrm{NO}_{3}{ }^{-}-\mathrm{N}_{\text {, }}$ $\mathrm{H}_{2} \mathrm{PO}_{4}^{-}-\mathrm{P}, \mathrm{K}^{+}, \mathrm{Ca}^{2+}$, and $\mathrm{Mg}^{2+}$ show a moderate autocorrelation with the nutrient concentrations of the previous week (week 1) but no correlations are found for longer periods. Nevertheless, no significant autocorrelations are found for $\mathrm{Cl}^{-}$and $\mathrm{Na}^{+}$concentrations over time.

Table 4. Autocorrelation of nutrient concentrations in petiole sap over time (1: determination in 7 days (1 week), 2: determination in 14 days ( 2 weeks), 3: determination in 21 days (3 weeks), and 4: determination in 28 days ( 4 weeks). To estimate the nutrient concentration of the following week, consider the nutrient concentration of the previous week.

\begin{tabular}{|c|c|c|c|c|c|c|}
\hline & & \multicolumn{4}{|c|}{ Lag } & \multirow[t]{2}{*}{ Equation } \\
\hline & & 1 & 2 & 3 & 4 & \\
\hline \multirow{7}{*}{ Petiole sap } & $\mathrm{Cl}^{-}$ & 0.11 & -0.18 & -0.11 & -0.24 & $y=0.1523 x+939.25$ \\
\hline & $\mathrm{NO}_{3}{ }^{-}-\mathrm{N}$ & $0.79^{*}$ & 0.55 & 0.30 & -0.01 & $y=0.8893 x+112.76$ \\
\hline & $\mathrm{H}_{2} \mathrm{PO}_{4}^{-}-\mathrm{P}$ & $0.61^{*}$ & 0.52 & 0.22 & -0.10 & $y=0.7148 x+27.994$ \\
\hline & $\mathrm{Na}^{+}$ & 0.28 & 0.12 & 0.00 & -0.41 & $y=0.2808 x+393.98$ \\
\hline & $\mathrm{K}^{+}$ & $0.68^{*}$ & 0.42 & 0.22 & 0.03 & $y=0.5778 x+1977.2$ \\
\hline & $\mathrm{Ca}^{2+}$ & $0.55^{*}$ & 0.36 & 0.12 & -0.01 & $y=0.7393 x+131.47$ \\
\hline & $\mathrm{Mg}^{2+}$ & $0.67^{*}$ & 0.37 & 0.10 & 0.01 & $y=0.9023 x+108.30$ \\
\hline
\end{tabular}

${ }^{*}$ indicates significant differences at $p<0.05$.

A stepwise regression approach for each nutrient was conducted in order to select the most fitted models with the minimum number of significant predictor variables. At each step of the stepwise procedure a new variable is entered or removed from the model based on the values of the partial F-test (F-value to enter or remove equal to 8). The regression coefficients and the independent variables selected by the stepwise regression procedure are shown in Table 5, along with the values of some goodness of fit statistics. 
Table 5. Parameters of linear multiple regression between petiole sap $\left(\mathrm{mg} \mathrm{L}^{-1}\right)$, climatic parameter $\left(\mathrm{ETc}\left(\mathrm{mm} \mathrm{day}^{-1}\right)\right.$, global radiation $\left(\mathrm{MJ} \mathrm{m}^{-2}\right.$ day), temperature $\left({ }^{\circ} \mathrm{C}\right)$, relative humidity $(\%)$, vapor pressure deficit (VPD) $(\mathrm{kPa})$, soil solution $\left(\mathrm{mmol} \mathrm{L}^{-1}\right)$, and the concentration of petiole sap of the last week (mg $\left.\mathrm{L}^{-1}\right)$ with $\mathrm{C}$ as the constant of the equation. Determination coefficient $\left(R^{2}\right)$, adjusted determination coefficient (Adj $\left.R^{2}\right)$, F-ratio, and $p$-value of the stepwise regression for each nutrient are evaluated, (-) no significative correlation between parameters.

\begin{tabular}{|c|c|c|c|c|c|c|c|c|c|c|c|c|}
\hline \multirow[b]{2}{*}{ Petiole Sap } & \multicolumn{9}{|c|}{ Regression Coefficients } & \multicolumn{3}{|c|}{ Statistics and Tests } \\
\hline & ETc & Rad. & Temp. & RH & VPD & LAI & SS & $\begin{array}{l}\text { Petiole Sap } \\
(\mathrm{t}-1)\end{array}$ & C & $\begin{array}{c}R^{2} \\
\left(\operatorname{Adj~} R^{2}\right) \\
\end{array}$ & F-Ratio & $p$-Value \\
\hline $\mathrm{Cl}^{-}$ & $82.28(17.27)$ & - & - & - & - & - & - & - & $964.96( \pm 30.86)$ & $76.42(73.04)$ & 22.68 & $<0.05$ \\
\hline $\mathrm{NO}_{3}{ }^{-}-\mathrm{N}$ & - & - & - & - & $1306.82( \pm 32.20)$ & - & - & - & $881.14( \pm 19.41)$ & $98.86(98.48)$ & 240.25 & $<0.05$ \\
\hline $\mathrm{H}_{2} \mathrm{PO}_{4}^{-}-\mathrm{P}$ & - & - & - & - & - & $-701.28( \pm 66.56)$ & - & - & $3259.22( \pm 301.66)$ & $95.69(94.82)$ & 111.01 & $<0.01$ \\
\hline $\mathrm{Na}^{+}$ & - & - & - & - & $69.29( \pm 26.71)$ & $-91.06( \pm 32.36)$ & - & - & $940.39( \pm 144.93)$ & 79.95 (71.93) & 9.97 & $<0.05$ \\
\hline $\mathrm{K}^{+}$ & $148.64( \pm 40.67)$ & - & - & - & - & $-1358.91( \pm 157.74)$ & - & - & $10240.80( \pm 740.18)$ & $97.39(96.09)$ & 74.71 & $<0.01$ \\
\hline $\mathrm{Ca}^{2+}$ & - & - & - & - & $469.83( \pm 54.18)$ & - & - & - & $435.65( \pm 15.24)$ & $94.94(94.68)$ & 75.18 & $<0.01$ \\
\hline $\mathrm{Mg}^{2+}$ & - & - & - & - & $399.63(120.49)$ & 1469.45 (186.95) & - & - & $-5072.22(826.88)$ & 97.09 (95.63) & 66.80 & $<0.01$ \\
\hline
\end{tabular}


All the adjusted models had a high goodness of fit since the coefficient of determinations $\left(R^{2}\right)$ was moderate for $\mathrm{Cl}^{-}$and $\mathrm{Na}^{+}$and high for $\mathrm{NO}_{3}{ }^{-}-\mathrm{N}, \mathrm{H}_{2} \mathrm{PO}_{4}{ }^{-}-\mathrm{P}, \mathrm{K}^{+}, \mathrm{Ca}^{2+}$, and $\mathrm{Mg}^{2+}$, respectively. In five cases, their values were higher than $94 \%$ and only in two cases were lower than $80 \%\left(76.42 \%\right.$ for $\mathrm{Cl}^{-}$ and $79.95 \%$ for $\mathrm{Ca}^{2+}$ ), which means that the adjusted models explain a high percentage of the nutrient petiole sap variability in all cases. In addition, the $p$-values for all the tests evaluated were less than 0.05 , indicating that there is a statistically significant relationship between the variables involved in each model at the $95 \%$ confidence level. It is interesting to point out that the only significant variables are ETc, DPV, and LAI. In four cases $\left(\mathrm{Cl}^{-}, \mathrm{NO}_{3}{ }^{-}-\mathrm{N}, \mathrm{H}_{2} \mathrm{PO}_{4}{ }^{-}-\mathrm{P}\right.$, and $\left.\mathrm{Ca}^{2+}\right)$ it was necessary to use one significant predictor variable whereas in the other three cases $\left(\mathrm{Na}^{+}, \mathrm{K}^{+}\right.$, and $\left.\mathrm{Mg}^{2+}\right)$ it was necessary to use two significant predictor variables.

\subsection{Correlations between Different Diagnostic Methods and Yield}

Table 6 shows the correlation coefficient between nutrient concentration in soil solution, petiole sap concentration, and leaf content with the yield obtained in tomato crops. The concentration of $\mathrm{NO}_{3}{ }^{-}-\mathrm{N}$, $\mathrm{H}_{2} \mathrm{PO}_{4}-\mathrm{P}$, and $\mathrm{K}^{+}$in petiole sap showed a high negative correlation with the yield $(r=-0.82,-0.77$, and -0.91$)$. On the contrary, soil solution only showed a positive correlation between $\mathrm{K}^{+}$concentration and yield. With respect to leaf content, it was the same trend in petiole sap since N, P, and $\mathrm{K}$ showed a high negative correlation with the yield $(r=-0.69,-0.52$, and -0.72 , respectively). Finally, it is important to point out that the petiole sap method shows the best coefficient of correlation with the yield compared to soil solution and leaf analysis.

Table 6. Correlation coefficients ( $\mathrm{r}$ ) between nutrient concentration in soil solution $\left(\mathrm{Cl}^{-}, \mathrm{NO}_{3}{ }^{-}, \mathrm{H}_{2} \mathrm{PO}_{4}{ }^{-}\right.$, $\mathrm{SO}_{4}{ }^{2-}, \mathrm{K}^{+}, \mathrm{Na}^{+}, \mathrm{Ca}^{2+}$, and $\left.\mathrm{Mg}^{2+}\right)\left(\mathrm{mmol} \mathrm{L}{ }^{-1}\right)$, petiole sap concentration $\left(\mathrm{Cl}^{-}, \mathrm{NO}_{3}{ }^{-}-\mathrm{N}_{1} \mathrm{H}_{2} \mathrm{PO}_{4}{ }^{-}-\mathrm{P}\right.$, $\mathrm{SO}_{4}{ }^{2-}-\mathrm{S}, \mathrm{K}^{+}, \mathrm{Na}^{+}, \mathrm{Ca}^{2+}$, and $\left.\mathrm{Mg}^{2+}\right)\left(\mathrm{mg} \mathrm{L}^{-1}\right)$, and leaf nutrient concentration $(\mathrm{N}, \mathrm{P}, \mathrm{K}, \mathrm{Na}$, and $\mathrm{Cl}(\mathrm{mg}$ $\left.\mathrm{g}^{-1} \mathrm{DW}\right)$ ) with tomato yield.

\begin{tabular}{ccccc}
\hline & \multicolumn{3}{c}{ Yield } \\
\hline Parameters & Petiole Sap & Soil Solution & \multicolumn{2}{c}{ Leaf } \\
\hline $\mathrm{Cl}^{-}$ & 0.20 & -0.03 & $\mathrm{Cl}$ & 0.25 \\
$\mathrm{NO}_{3}{ }^{-}-\mathrm{N}$ & $-0.82^{*}$ & -0.02 & $\mathrm{~N}$ & $-0.69^{*}$ \\
$\mathrm{H}_{2} \mathrm{PO}_{4}^{-}-\mathrm{P}$ & $-0.77^{*}$ & 0.05 & $\mathrm{P}$ & $-0.52^{*}$ \\
$\mathrm{Na}^{+}$ & 0.23 & -0.23 & $\mathrm{Na}$ & 0.34 \\
$\mathrm{~K}^{+}$ & $-0.91^{*}$ & $0.68^{*}$ & $\mathrm{~K}$ & $-0.72^{*}$ \\
$\mathrm{Ca}^{2+}$ & 0.16 & -0.26 & & \\
$\mathrm{Mg}^{2+}$ & 0.25 & -0.25 & & \\
\hline
\end{tabular}

${ }^{*}$ indicates significant differences at $p<0.05$. ns indicates non-significant differences.

\section{Discussion}

Concerning climatic parameters, the range of ETc obtained in our trial (1.2 to $2.4 \mathrm{~mm} \mathrm{day}^{-1}$ ) was within the ranges proposed by Fernández et al. [25] and Baeza et al. [26], who established a minimum value of 0.5 and a maximum value of $2.4 \mathrm{~mm} \mathrm{day}^{-1}$. The range of global radiation in our experiment was from 6.7 to $8.0 \mathrm{MJ} \mathrm{m}^{-2}$ day ${ }^{-1}$ and was inside in the range of 5 to $11 \mathrm{MJ} \mathrm{m}^{-2}$ day $^{-1}$ reported by Baeza et al. [26] for the production of tomato in Mediterranean greenhouses. The range of temperature during the experiment $\left(10\right.$ to $\left.17^{\circ} \mathrm{C}\right)$ was in line with the findings reported by Baeza et al. [26] who established a range from 4 to $25^{\circ} \mathrm{C}$ inside the greenhouse in a tomato crop. Finally, the average relative humidity in our experiment ( $85 \%$ of $\mathrm{RH}$ ) was inside the range established by Baudoin et al. [27] (70\%-90\% of RH) for a tomato crop in the Mediterranean area.

As far as plant parameters are concerned, the values of LAI in our experiment ranged from 4.2 to 4.6. These values were inside the range (3.8 to 4.7) reported by different researchers such as Barraza et al. [28] and Medrano et al. [17]. Finally, the yield obtained in our experiment was lower compared to 
the production of this area with an average of $9.56 \mathrm{~kg} \mathrm{~m}^{-2}$ [29]. This yield reduction can be due to the low daily radiation inside the greenhouse, since Baudoin et al. [27] recommended a minimum daily radiation in tomato of around $8.5 \mathrm{MJ} \mathrm{m}^{-2}$ day $^{-1}$. Similiarly, Sandri et al. [30] and Llanderal et al. [31] reported the same results in a tomato greenhouse crop.

The mean values for $\mathrm{pH}, \mathrm{EC}$, and nutrient concentrations in soil solution in our experiment ( $\mathrm{pH}(7.5-8.1)$ and EC (2.1-4.1 dS m$\left.{ }^{-1}\right)$ values and concentration of $\mathrm{H}_{2} \mathrm{PO}_{4}^{-}\left(0.1-0.2 \mathrm{mmol} \mathrm{L}^{-1}\right), \mathrm{K}^{+}$ (3.1-7.6 mmol L-1), $\mathrm{Ca}^{2+}\left(2.5-5.9 \mathrm{mmol} \mathrm{L}{ }^{-1}\right), \mathrm{Mg}^{2+}\left(2.5-11.3 \mathrm{mmol} \mathrm{L}^{-1}\right), \mathrm{Cl}^{-}\left(1.3-13.2 \mathrm{mmol} \mathrm{L}^{-1}\right)$, and $\mathrm{Na}^{+}\left(2.5-11.3 \mathrm{mmol} \mathrm{L}^{-1}\right)$ were inside the optimal ranges proposed by Lao et al. [19]. On the other hand, the range of $\mathrm{NO}_{3}{ }^{-}$concentration was higher than the optimal range proposed by Lao et al. [19] ( $\mathrm{NO}_{3}{ }^{-}$6.4-19 mmol L$\left.{ }^{-1}\right)$. The higher $\mathrm{NO}_{3}{ }^{-}$concentration found in our experiment can be related to an excessive nitrogen input which is well above the nutritional requirements of the crop.

The mean values of nutrient concentrations in petiole sap in our experiment were inside the optimal range proposed by Cadahía [12] for $\mathrm{H}_{2} \mathrm{PO}_{4}^{-}-\mathrm{P}\left(35-135 \mathrm{mg} \mathrm{L}^{-1}\right), \mathrm{K}^{+}\left(600-4590 \mathrm{mg} \mathrm{L}^{-1}\right), \mathrm{Ca}^{2+}$ (280-1420 mg L$\left.{ }^{-1}\right)$, and $\mathrm{Mg}^{2+}\left(190-200 \mathrm{mg} \mathrm{L}^{-1}\right)$ concentrations, and for $\mathrm{Cl}^{-}$and $\mathrm{Na}^{+}$, the values in our experiment were inside in the optimal range proposed by Urrestarazu [15] (750-4500 and 50-400 $\mathrm{mg} \mathrm{L}^{-1}$, respectively). On the other hand, the range of $\mathrm{NO}_{3}{ }^{-}-\mathrm{N}$ concentration was higher than the optimal range proposed by Cadahía [12] (133-1000 $\mathrm{mg} \mathrm{L}^{-1}$ ). The high concentration of $\mathrm{NO}_{3}{ }^{-}-\mathrm{N}$ in sap over our trial could be a result of the excess of $\mathrm{NO}_{3}{ }^{-}$in the soil solution (SS) due to the high supply of nitrogen fertilizers, which is in agreement with Fontes and Ronchi [32] who found a positive correlation between $\mathrm{NO}_{3}{ }^{-}$concentration in soil solution and in petiole sap. Moreover, the high concentration of $\mathrm{NO}_{3}{ }^{-}-\mathrm{N}$ in sap over our trial could be due to the low light intensity inside the greenhouses because under low-light conditions, there is a decrease in the activity of nitrate reductase as reported by Llanderal [9].

The mean values of leaf nutrient concentration in our experiment were inside the optimal ranges for $\mathrm{N}$ (25-48), P (2.6-4.7), and K (16-31 $\left.\mathrm{mg} \mathrm{g}^{-1} \mathrm{DW}\right)$ proposed by Llanderal et al. [33] and higher than the optimal values proposed by Casas and Casas [34] for $\mathrm{Cl}\left(<5 \mathrm{mg} \mathrm{g}^{-1}\right)$ and $\mathrm{Na}\left(<1.8 \mathrm{mg} \mathrm{g}^{-1} \mathrm{DW}\right)$.

The variability of nutrient concentrations in sap are associated with several factors, such as climatic parameters, leaf area index, nutrient concentrations in soil solution, and the previous nutrient concentrations in petiole sap. All nutrient concentrations in the petiole sap showed a positive correlation with the crop ETc, and this can be related to the reduction of the water content in the plant as suggested by Hochmuth [2]. No significant correlation between nutrient concentrations and temperature was found. The only significant correlation between $\mathrm{RH}$ and nutrient concentrations in sap was for $\mathrm{Ca}^{2+}$. These results are in line with the findings reported by Armstrong and Kirkby [35] who established that under high relative humidity conditions $(95 \%)$, the nutrient uptake of calcium by mass flow was restricted. No correlation between $\mathrm{NO}_{3}{ }^{-}-\mathrm{N}$ concentration and $\mathrm{RH}$ was found in our experiment and this could be due to the fact that $\mathrm{NO}_{3}{ }^{-}-\mathrm{N}$ concentration is independent of the $\mathrm{RH}$ conditions as proposed by Erica et al. [36].

No relationship between $\mathrm{Cl}^{-}, \mathrm{H}_{2} \mathrm{PO}_{4}^{-}-\mathrm{P}, \mathrm{Na}^{+}, \mathrm{K}^{+}$, and $\mathrm{Mg}^{2+}$ concentrations in sap and $\mathrm{RH}$ is due to the fact that ions such as $\mathrm{Cl}^{-}, \mathrm{H}_{2} \mathrm{PO}_{4}^{-}-\mathrm{P}, \mathrm{Na}^{+}, \mathrm{K}^{+}$, and $\mathrm{Mg}^{2+}$ are considered mobile in the phloem, so they can be deposited in plant organs or translocated [14,37].

The increase of nutrient concentration in sap could be related to the reduction of water content in the plant, since crop transpiration increases with increasing atmospheric vapor pressure deficit (VPD) [38]. In plant parameters, $\mathrm{LAI}$ has a negative correlation with $\mathrm{Cl}^{-}, \mathrm{NO}_{3}{ }^{-}-\mathrm{N}, \mathrm{H}_{2} \mathrm{PO}_{4}^{-}-\mathrm{P}, \mathrm{K}^{+}$, and $\mathrm{Na}^{+}$concentration in sap which can be due to the dilution factor related to biomass increase proposed by Opstad [39]. On the other hand, there was a positive correlation with $\mathrm{Ca}^{2+}$ and $\mathrm{Mg}^{2+}$ due to the accumulation of these ions over the crop cycle as reported by Llanderal [9]. No correlation between nutrient concentrations in sap and soil solution is due to the fact that the concentrations in soil solution were in the optimal range as proposed by Lao et al. [19]. Nevertheless, the physiological process such as nutrients uptake, bio-assimilation, and storage affect the nutrient concentrations in sap [9].

The significant autocorrelation over the crop cycle of $\mathrm{NO}_{3}{ }^{-}-\mathrm{N}, \mathrm{H}_{2} \mathrm{PO}_{4}{ }^{-}-\mathrm{P}, \mathrm{K}^{+}, \mathrm{Ca}^{2+}$, and $\mathrm{Mg}^{2+}$ concentration relates to the capacity of plants to regulate nutrient concentrations in response to changes 
in environmental conditions [40]. However, no significant autocorrelation of $\mathrm{Cl}^{-}$and $\mathrm{Na}^{+}$over the experimental period occured due to the regulation developed by some wild tomato species through the accumulation of these ions into the vacuole for their osmotic regulation [41], which in turn can be diluted for a growth and succulence mechanism as proposed by Cuartero et al. [42].

Finally, comparing the different diagnostic methods established with the yield, our results report that the petiole sap method shows the best coefficient of correlation. The negative correlation in petiole sap $\left(\mathrm{NO}_{3}{ }^{-}-\mathrm{N}, \mathrm{H}_{2} \mathrm{PO}_{4}{ }^{-} \mathrm{P}\right.$, and $\left.\mathrm{K}^{+}\right)$and leaf analysis $(\mathrm{N}, \mathrm{P}$, and $\mathrm{K})$ can be due to the dilution factor as a consequence of the increase of growth and yield in the plant [31,43]. Moreover, the negative correlation can be due to the translocation of these nutrients to the fruit [44]. On the other hand, it is necessary to point out that the positive correlation between $\mathrm{K}^{+}$concentration in soil solution and yield is in line with the findings reported by Bugarín-Montoya et al. [45] who proposed the same positive correlation in tomato crop.

\section{Conclusions}

The method of petiole sap shows the best coefficient of correlation with the yield, compared with the different diagnostic methods established: soil solution and leaf nutrient concentrations; therefore, nutrient sap concentration can be recommended as the most sensitive nutritional diagnosis methods related to the expected yield.

The highest problem of sap diagnosis methods is the wide range of nutrient concentrations related to optimal nutrient status. In this paper, a model is proposed to determine the nutrient concentrations in petiole sap in response to climatic parameters, nutrients in soil solution, and growth. The ETc, DPV, and LAI are the most significant variables that allow the development of these empirical prediction models regarding nutrient concentrations in petiole sap. It is important to highlight that the reduction of the water content in the plant increases the concentration of all the nutrients in petiole sap.

The high autocorrelation of nutrient concentrations in sap for one week suggests that a longer sampling period is needed in order to analyze the nutrient change in sap, therefore we recommend that the best option is a sampling period of 15 days. Nevertheless, it is necessary for other experiments to further support and confirm these findings due to the scarcity of previous knowledge.

Author Contributions: Investigation, data curation, writing-original draft preparation, A.L.; formal analysis, investigation, P.G.-C., J.P.-A., J.I.C., M.L.S., and J.R.; conceptualization, supervision, project administration, M.T.L. All authors have read and agreed to the published version of the manuscript.

Conflicts of Interest: The authors declare no conflicts of interest.

\section{Abbreviations}

The following abbreviations are used in this manuscript:

$\begin{array}{ll}\text { ETc } & \text { Crop evapotranspiration } \\ \text { DAT } & \text { Days after transplanting } \\ \text { HPLC } & \text { High-performance liquid chromatography } \\ \text { LAI } & \text { Leaf area index } \\ \text { PAR } & \text { Radiation photosynthetically active } \\ \text { RH } & \text { Relative humidity } \\ \text { SS } & \text { Soil solution } \\ \text { VPD } & \text { Vapor pressure deficit }\end{array}$

\section{References}

1. Jones, J.B.; Wolf, B.; Mills, H.A. Tissue testing. In Plant Analysis Handbook; Micro-Macro Publications: Athens, Greece, 1991; pp. 99-104.

2. Hochmuth, G.J. Sufficiency ranges for nitrate-nitrogen and potassium for vegetable petiole sap quick tests. HortTechnology 1994, 4, 218-222. [CrossRef]

3. Smith, D.L. Rockwool in Horticulture; Grower Books: London, UK, 1987; p. 156. 
4. Farneselli, M.; Tei, F.; Simonne, E.H. Reliability of petiole sap test for N nutritional status assessing in processing tomato. J. Plant Nutr. 2014, 37, 270-278. [CrossRef]

5. Studstill, D.W.; Simonne, E.H.; Hutchinson, C.M.; Hochmuth, R.C.; Dukes, M.D.; Davis, W.E. Petiole sap testing sampling procedures for monitoring pumpkin nutritional status. Commun. Soil Sci. Plant Anal. 2004, 34, 2355-2362. [CrossRef]

6. Bates, T.E. Factors affecting critical nutrient concentrations in plants and their evaluation: a review. Soil Sci. 1971, 112, 116-130. [CrossRef]

7. Mills, H.A.; Benton, J.J. Plant. Analysis Handbook II: A Practical Sampling, Preparation, Analysis, and Interpretation Guide; Micro Macro Publisher: Athens, Greece, 1996; p. 422.

8. Hartz, T.K. The assessment of soil and crop nutrient status in the development of efficient fertilizer recommendations. Acta Hortic. 2003, 627, 231-240. [CrossRef]

9. Llanderal, A. Study of diagnostic methods and evaluation of nutritional parameters in the intensive horticulture cropping systems as basis for a sustainable management of the fertigation. Ph.D. Thesis, University of Almeria, La Canada, Spain, September 2017.

10. Ikeda, H. Research reports for national science research foundation for 1992-1994 (Research B); Development of New Nutrition Diagnosis Methods for Horticultural Crops: Tokyo, Japan, 1995. (In Japanese)

11. Leyva, G.; Sánchez, P.; Alcántar, G.; Valenzuela, J.G.; Gavi, F.; Martínez, Á. Contenido de nitratos en extracto celulares de pecíolos y frutos de tomate. Rev. Fitotec. Mex. 2005, 28, 145-150.

12. Cadahía, C. Fertirrigación. La savia como índice de fertirrigación en cultivos agroenergéticos, hortícolas, frutales y ornamentales; Mundi-Prensa: Madrid, Spain, 2008; p. 256.

13. García, M.E.; Azuara, P. Evaluation of the most adequate organ of reference for sap analysis in the tomato plant. Biol. Plant. 1991, 33, 91-96. [CrossRef]

14. Llanderal, A.; García-Caparrós, P.; Contreras, J.I.; Segura, M.L.; Lao, M.T. Evaluation of the nutrients variability in sap of different petiole samples in tomato plant. Commun. Soil Sci. Plant Anal. 2018, 49, 745-750. [CrossRef]

15. Urrestarazu, M. Tratado de cultivos sin suelo; Mundi-Prensa: Madrid, Spain, 2004; p. 914.

16. Lao, M.T. The mulching sandy soil and their management fertigation in horticultural production. Trends Soil Sci. 2004, 3, 71-82.

17. Medrano, E.; Sánchez-Guerrero, M.A.; Lorenzo, P.; Alonso, F.J. Relaciones hídricas y programación de riego en cultivos hortícolas en sustratos; IFAPA: Escobar Impresores, S.L.: El Ejido, Spain, 2008; p. 88.

18. Bailey, B.J.; Montero, J.I.; Biel, C.; Wilkinson, D.J.; Anton, A.; Jolliet, O. Transpiration of Ficus benjamina: comparison of measurements with predictions of the Penman-Monteith model and a simplified version. Agric. For. Meteorol. 1993, 65, 229-243. [CrossRef]

19. Lao, M.T.; González, J.I.; Jiménez, S. Manual para la gestión del fertirriego en los invernaderos de Almería; Junta de Andalucía Consejo de Agricultura y Pesca: Sevilla, Spain, 2002; p. 30.

20. Csáky, A.; Martínez-Grau, M.A. Técnicas Experimentales en Síntesis Orgánica; Síntesis: Madrid, Spain, 1998.

21. Cadahía, C. El análisis de la savia como índice de fertilización. Manuales de la Ciencia actual; CSIC: Madrid, Spain, 1973.

22. Krom, M.D. Spectrophotometric determination of ammonia: study of a modified Berthelot reaction using salicylate and dicholoroisocyanurate. Analyst 1980, 105, 305-316. [CrossRef]

23. Hogue, E.; Wilcow, G.E.; Cantliffe, D.J. Effect of soil $\mathrm{P}$ on phosphate fraction in tomato leaves. J. Am. Soc. Hort. Sci. 1970, 95, 174-176.

24. Lachica, M.; Aguilar, A.; Yañez, J. Análisis foliar: Métodos utilizados en la Estación Experimental del Zaidín. Anal. Edaf. Agrobio. 1973, 32, 1033-1047.

25. Fernández, M.D.; Orgaz, F.; Fereres, E.; López, J.C.; Céspedes, A.; Pérez, J.; Gallardo, M. Programacion del riego de cultivos horticolas bajo invernadero en el sudeste español. Estacion Experimental Cajamar, 2nd Ed. ed; El Ejido: Almería, Spain, 2005; p. 71.

26. Baeza, R.; Alonso, F.; Contreras, J.I. Cálculo de la evapotranspiración en cultivo de tomate en invernadero. Utilización de series climáticas históricas vs. a tiempo real. XIV. Congr. Nac. Cienc. Hort. Retos Nueva Agric. Mediterr. 2015, 71, 248-251.

27. Baudoin, W.; Nono-Womdim, R.; Lutaladio, N.B.; Hodder, A. Good Agricultural Practices for Greenhouse Vegetable Crops: Principles for Mediterranean Climate Areas; Food and Agriculture Organization (FAO) of the United Nations: Rome, Italy, 2013; p. 616.

28. Barraza, F.V.; Fischer, G.; Cardona, C.E. Studying the process of tomato crop (Lycopersicon esculentum Mill.) growth in the Middle Sinu Valley, Colombia. Agron. Colom. 2004, 22, 81-90. 
29. Valera, D.M.; Belmonte, L.; Molina, F.D.; López, A. Greenhouse Agriculture in Almería: A Comprehensive Techno-Economic Analysis; Cajamar, Caja Rural: Almeria, Spain, 2016; p. 408.

30. Sandri, M.A.; Andriolo, J.L.; Witter, M.; Dal Ross, T. Effect of shading on tomato plants grow under greenhouse. Hortic. Bras. 2003, 21, 642-645. [CrossRef]

31. Llanderal, A.; García-Caparrós, P.; Contreras, J.I.; Segura, M.L.; Lao, M.T. Testing foliar nutritional changes in space and over time in greenhouse tomato. J. Plant Nutr. 2019, 42, 333-343. [CrossRef]

32. Fontes, P.C.R.; Ronchi, C.P. Critical values of nitrogen indices in tomato plants grown in soil and nutrient solution determined by different statistical procedures. Pesq. Agropec. Bras. 2002, 37, 1421-1429. [CrossRef]

33. Llanderal, A.; Lao, M.T.; Contreras, J.I.; Segura, M.L. Diagnosis and recommendation integrated system norms and sufficiency ranges for tomato greenhouse in Mediterranean climate. HortScience 2018, 53, 479-482. [CrossRef]

34. Casas, A.; Casas, E. Análisis de suelo-agua-planta y su aplicación en la nutrición de cultivos hortícolas en la zona del sureste peninsular; Caja Rural Almería: Almería, Spain, 1999; p. 156.

35. Armstrong, M.J.; Kirkby, E.A. The influence of humidity on the mineral composition of tomato plants with special reference to calcium distribution. Plant Soil 1979, 52, 427-435. [CrossRef]

36. Erica, B.; Larsson, C.M.; Larsson, M. Responses of nitrate assimilation and N translocation in tomato (Lycopersicon esculentum Mill) to reduced ambient air humidity. J. Exp. Bot. 1996, 47, 855-861. [CrossRef]

37. Siebrecht, S.; Herdel, K.; Schurr, U.; Tischner, R. Nutrient translocation in the xylem of poplar diurnal variations and spatial distribution along the shoot axis. Planta 2003, 217, 783-793. [CrossRef] [PubMed]

38. Fletcher, A.; Sinclair, T.R.; Allen, L.H. Transpiration responses to vapor pressure deficit in well-watered 'slow-wilting' and conventional soybeans. Environ. Exp. Bot. 2007, 61, 145-151. [CrossRef]

39. Opstad, N. Mineral concentrations in leaf dry matter and leaf and petiole sap in strawberry depend on leaf age and plant developmental stage. Acta Hortic. 2010, 868, 143-148. [CrossRef]

40. Chrispeels, M.J.; Crawford, N.M.; Schroeder, J.I. Proteins for transport of water and mineral nutrients across the membranes of plant cells. Plant Cell 1999, 11, 661-675. [CrossRef]

41. Jeschke, W.D.; Pate, J.S. Cation and chloride partitioning through xylem and phloem within the whole plant of Ricinus communis L. under conditions of salt stress. J. Exp. Bot. 1991, 42, 1105-1116. [CrossRef]

42. Cuartero, J.; Yeo, A.R.; Flowers, T.J. Selection of donors for salt- tolerance in tomato using physiological traits. New Phytol. 1992, 121, 63-69. [CrossRef]

43. Mourão-Filho, F.D.A.A. DRIS: Concepts and applications on nutritional diagnosis in fruit crops. Sci. Agric. 2004, 61, 550-560. [CrossRef]

44. Betancourt, P.; Pierre, F. Extraccion de macronutrientes por el cultivo de tomate (Solanum lycopersicum Mill. var. Alba) en casas de cultivo en Quíbor, estado Lara. Bioagro 2013, 25, 181-188.

45. Bugarín-Montoya, R.; Glavis-Spinola, A.; Sánchez-García, P.; García-Paredes, D. Daily accumulation of aboveground dry matter and potassium in tomato. Terra latinoam. 2002, 20, 401-409. 